\title{
PHYSICAL AND BIOCHEMICAL QUALITY PROPERTIES OF FERMENTED BEEF SAUSAGES: BEZ SUCUK
}

\author{
Ü. ÇiçEK* and T. KöSE \\ Department of Food Engineering, Faculty of Engineering and Natural Sciences, Gaziosmanpaşa University, \\ 60100, Tokat. Turkey
}

(Received: 21 May 2015; accepted: 25 June 2015)

\begin{abstract}
In this study, sucuk samples were obtained from 12 different manufacturers to evaluate some physical and biochemical properties of fermented beef sausages named as "bez sucuk". It was seen that the titratable acidity values were between $1.02 \%$ and $2.25 \%$ lactic acid, and $\mathrm{pH}$ values of the samples ranged from 5.08 to 5.63 ( $\mathrm{P}<0.05)$. $\mathrm{L} * \mathrm{a} * \mathrm{~b} *$ values of the samples were in the ranges of $38.99-47.15,10.77-20.94$, and $13.88-32.41$, respectively $(\mathrm{P}<0.05)$. Residual nitrite was detected from group 1,2 , and $4(\mathrm{P}<0.05)$. The free fatty acid, peroxide, and thiobarbituric acid values of the fermented sausages were in the ranges of $3.01-14.34 \%$ oleic acid, $7.40-13.63$ $\mathrm{meqO}_{2} / \mathrm{kg}$ fat, and $0.75-1.17 \mathrm{mg}$ malonaldehyde $/ \mathrm{kg}$ sample, respectively $(\mathrm{P}<0.05)$.

Keywords: fermented beef sausage, cloth casings, color, lipid oxidation
\end{abstract}

Traditional dry-fermented sausage named as sucuk, is a well-known and a very popular fermented meat product in Turkey (ENsoy et al., 2010), the manufacturing process of sucuk varies regionally, and different formulations exist (BOZKURT \& ERKMEN, 2004). Bez sucuk is a type of Turkish traditional fermented sausage and the sucuk mixture is filled into cloth casings instead of natural casings. These casings could be easily obtained from many sellers of herbs in Tokat province. The cloth casings are sewed generally with a size of $7 \times 25 \mathrm{~cm}$ from noncolored cloth containing 42 threads per $\mathrm{cm}^{2}$. The bez sucuk that is manufactured especially in Tokat province is sold by supermarkets and at electronic shopping web pages all over the country. Although the production and consumption amounts of this product are considerably high, the formulations and process conditions (temperature, time, and humidity) of this product show differences among the manufacturers in the city (KAVAL et al., 2010; TURHAN et al., 2010). Butchers are the main manufacturers of this product, but a few small scaled facilities also produce bez sucuks (Kaval et al., 2010). Bez sucuk is produced by traditional methodologies without adding starter culture, the production stages of the product are as follows: i) the mixing of ground beef meat and beef carcass fat with spices, ii) stuffing the sucuk mix into cloth casings, and iii) ripening for 10-14 days (generally utilized only by the facilities). During the ripening period, bez sucuks are generally pressed with a cylindirical roller for two or three times to give its characteristic shape and texture (KAVAL et al., 2010). Although butchers generally start selling the product following the filling stage, the product should be sold after the 10th day of the ripening period, after the $\mathrm{pH}$ drop, which affects the microbial quality and the textural properties of the product.

In Tokat, meat facilities have shown increasing interest in the manufacturing of bez sucuk in the last decade, however, sucuks are still produced mainly by butchers applying different processing procedures. We aimed to determine the general characteristics of bez sucuks produced in Tokat province.

\footnotetext{
* To whom correspondence should be addressed.

Phone: +90 356 2521616-2926; fax: +90 356 2521729; e-mail: umran.ensoy@gop.edu.tr
} 


\section{Materials and methods}

In this study, bez sucuks were obtained from 12 different manufacturers consisting of 10 butchers and two small scaled facilities at each sampling period. Samples were taken from three different production time of each manufacturer, and two samples were obtained for further analysis at each visit. Bez sucuk groups collected from 10 butchers were coded as 2 , $3,5,6,7,8,9,10,11$, and 12 , while the bez sucuk groups obtained from small scaled facilities were coded as 1 and 4 .

Moisture, protein $(\mathrm{N} \times 6.25)$, fat, and ash contents were determined in duplicate following AOAC (2006) methods numbered as 950.46, 928.08, 960.39, and 920.153, respectively. Salt and hydroxyproline (HP) contents of samples were analyzed by using the methods of LeES (1975) and YANG and FroniNg (1992), respectively. The pH of the samples was determined using an Orion $420 \mathrm{~A} \mathrm{pH}$-meter, then sample slurries were titrated with $0.1 \mathrm{~N} \mathrm{NaOH}$ to an endpoint of $\mathrm{pH}$ 8.30. The meq of $\mathrm{NaOH}$ were converted to and expressed as percent lactic acid (CANDOĞAN, 2000). The water activity values of the samples were measured by using AquaLab Series 3 TE model (USA) at each sampling stages (KaVAL et al., 2010). The measurements of CIE* $\mathrm{L}^{*}$ (lightness), $\mathrm{a}^{*}$ (redness), and $\mathrm{b}^{*}$ (yellowness) values were carried out immediately after slicing, and repeated five times in different slices of the samples by using Minolta Chrometer CR300 (Japan) (ÜREN \& BABAYIĞIT, 1997). The lipids were extracted from $100 \mathrm{~g}$ of samples with a solvent mixture of chloroform:methanol (2:1) using a sample:solvent ratio of 1:2 (BLIGH \& Dyer, 1959). Free fatty acid (FFA) content was determined as oleic acid (OA) \% according to AOAC (1996) method number 940.28. The results were expressed as oleic acid in percent. Peroxide value (PV) of bez sucuks was measured according to AOCS (1994) method numbered as Cd 8b-90. The results were expressed as meqO $/ 2$ kg fat. Thiobarbituric acid (TBA) value was determined as milligram of malondialdehyde (MA) per kilogram of sample using the method of TARLADGIS and coworkers (1960). The readings were multiplied by the factor of 7.8 to convert to milligrams of MA per kilogram of sample. The residual nitrite contents of samples were measured according to VURAL and ÖZTAN (1996). The optical density of the samples was read against the blank at a wavelength of $540 \mathrm{~nm}$ using a UNICAM UV/Vis spectrophotometer (ThermoScientific, Milan, Italy). The standard curve was also prepared by the same method and the residual nitrite content was expressed as $\mathrm{mg}$ nitrite $/ \mathrm{kg}$ sample. The data were statistically analyzed by using the statistical package SPSS 20.0 (International154 Business Machines Corporation (IBM) Armonk, NY, USA). Mean values for bez sucuk manufacturers were compared using analysis of variance (ANOVA) with the Duncan multiple post hoc comparison test to evaluate statistical significance between the means $(\mathrm{P}<0.05)$.

\section{Results and discussion}

The proximate compositions of bez sucuks obtained from 12 different manufacturers are given in Table 1. The highest and lowest moisture contents were measured in the samples 10 and 8 obtained from butchers as $49.96 \%$ and $33.20 \%$, respectively $(\mathrm{P}<0.05)$. According to both TS 1070 Turkish Sucuk Standard (TSE, 2002) and Turkish Food Codex-Meat Products Communique (Republic of Turkey Ministry of Food, Agriculture and Livestock, 2012), the maximum moisture content of Turkish sucuks should be $40 \%$. It was found that the moisture contents of samples 2, 3, 5, 10, 11, and 12 were higher than the maximum allowed 
moisture content stated in both the standard and the communique. The butchers generally start to sell bez sucuks following the filling stage, thus, this selling strategy resulted in different and unstandard bez sucuks having different chemical compositions. The goal of this study was to point out the unstandard production of bez sucuks, especially by butchers, and to refer them to manufactured bez sucuks in accordance with the food legislation. TURHAN and co-workers (2010) also reported that the moisture contents of bez sucuks were in a wide range of $17.95-46.37 \%$. According to sucuk standard (TSE, 2002), the minimum protein content of Turkish sucuks should be more than $20 \%$, while the minimum protein content is limited to $16 \%$ in the communique (Republic of Turkey Ministry of Food, Agriculture AND Livestock, 2012). In this study, the protein contents of bez sucuks were between $15.64 \%$ and $27.38 \%$ (Table 1) $(\mathrm{P}<0.05)$. Similar results were also obtained by TuRHAN and co-workers (2010). Among the bez sucuk groups, it was seen that the protein content of sample 10 was lower than the protein content stated in the communique (RePUBLiC OF TURKey Ministry of Food, Agriculture And Livestock, 2012), while the samples 3, 5, 10, 11, and 12, obtained from butchers, had lower protein contents than stated in sucuk standard (TSE, 2002). It was determined that the fat content of bez sucuks were in a range of $27.05-33.72 \%(\mathrm{P}<0.05)$ (Table 1), thus, the fat content of all samples exceeded the allowed fat contents stated in sucuk standard (TSE, 2002). TURHAN and co-workers (2010) reported that the fat contents of bez sucuks were in a range of $17-45 \%$. The ash contents of sucuks were in a range of 3.28$6.81 \%$, and the difference between the ash contents of bez sucuks was statistically significant $(\mathrm{P}<0.05)$ (Table 1). In another study, it was reported that the ash contents of bez sucuks were between $3.50 \%$ and $4.74 \%$ (TURHAN et al., 2010). The different amounts of seasonings and salt used resulted in different ash contents. It is stated in sucuk standard (TSE, 2002) that Turkish sucuks should contain salt in less than $5 \%$. The salt contents of all samples were between $1.71 \%$ and $4.88 \%(\mathrm{P}<0.05)$ (Table 1$)$, and the results were in accordance with sucuk standard (TSE, 2002). The maximum hydroxyproline (HP) content of Turkish sucuks is limited to $225 \mathrm{mg} \mathrm{HP} / 100 \mathrm{~g}$ of sample in sucuk standard (TSE, 2002). It was determined that HP contents of sucuks were in a range of 130.9-374.6 mg HP/100 $\mathrm{g}(\mathrm{P}<0.05)$, thus, the HP contents of samples $1,2,5$, and 11 varying between 130.9 and $199.4 \mathrm{mg} \mathrm{HP} / 100 \mathrm{~g}$ were lower than the HP content stated in sucuk standard (TSE, 2002) ( $P>0.05)$, while the other samples had higher HP contents, which may be due to using beef meat rich in connective tissue. Additionally, the maximum collagen content is limited to $20 \%$ of total protein of Turkish sucuks in the communique (Republic of Turkey Ministry of Food, Agriculture and LivESTOCK, 2012). It was seen that all samples had lower collagen content than stated in the communique (Table 1). The residual nitrite was only measured in samples 1, 2, and 4 (Table 1), though sample 2 was obtained from a butcher. It was seen that butchers could utilize curing agents in the formulation of bez sucuks without any control and declaring the nitrite utilization to consumers. The maximum nitrite amount in the formulation of Turkish sucuks is limited in Turkish Food Codex-Food Additives Legislation to 250 ppm (Republic of Turkey Ministry of Food, Agriculture and Livestock, 2013), while the residual nitrite value was limited in sucuk standard to $50 \mathrm{ppm}$ (TSE, 2002). The bez sucuk groups mentioned above had lower residual nitrite value than allowed in the sucuk standard (Tse, 2002). ÜREN and BABAYIĞIT (1997) also reported similar results for Turkish sucuks, which were between 2.51 and $11.25 \mathrm{ppm}$. On the other hand, Johansson and co-workers (1994) stated that the fermented sausages produced with starter cultures had no residual nitrite after the 14th day of the ripening period. This could be explained by the lower nitrite amount needs in the formulation of fermented sausages. 


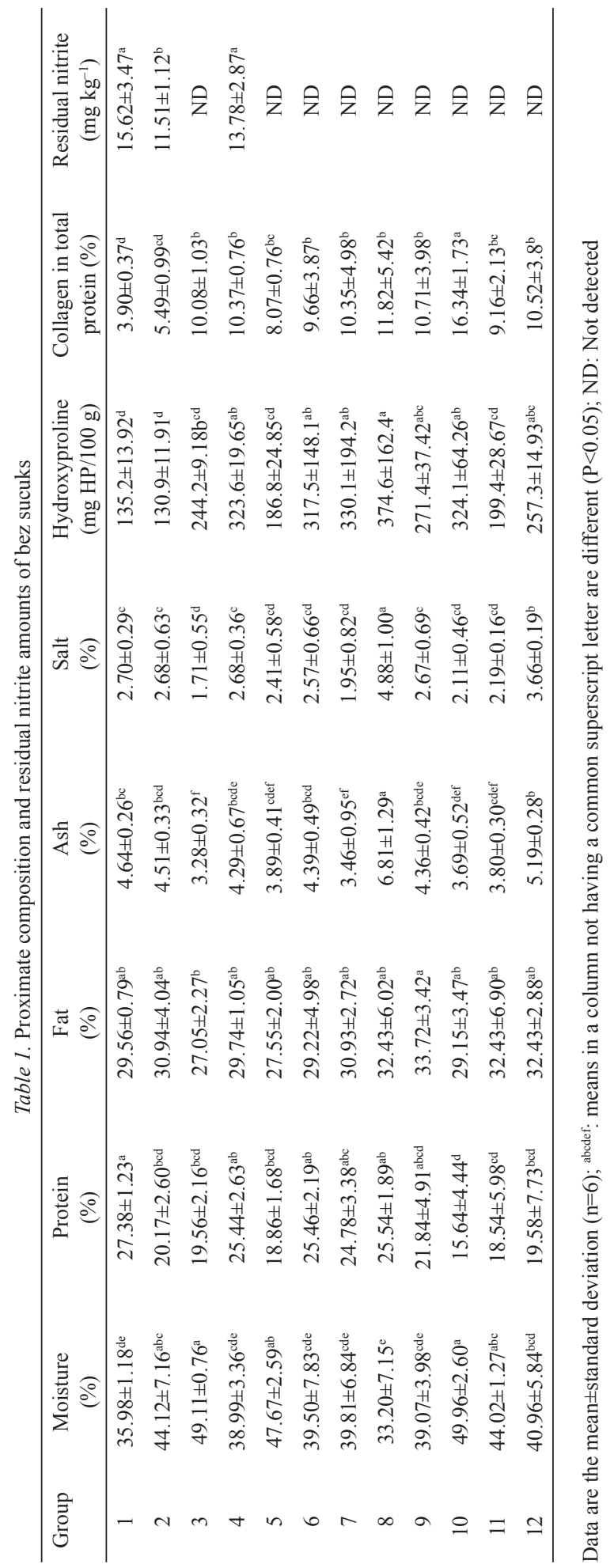


The $\mathrm{pH}$, titratable acidity, and water activity values of bez sucuks obtained from both butchers and small scaled facilities are given in Table 2. The $\mathrm{pH}$ values of bez sucuks ranged between 5.08 and 5.66. It was stated in both the sucuk standard (TSE, 2002) and the communiqué (Republic of Turkey Ministry of Food, Agriculture and Livestock, 2012) that the $\mathrm{pH}$ of Turkish sucuks should be less than 5.4. While the $\mathrm{pH}$ values of the sucuk samples 1 and 4 obtained from the facilities were 5.18 and 5.29 , respectively, the samples 2,6 , and 8 had higher $\mathrm{pH}$ values than allowed in the standard and the communique $(\mathrm{P}<0.05)$. Similar results were also reported by many researchers (TURHAN et al., 2010; KAVAL et al., 2010). The increasing lactic acid content results in decrease in $\mathrm{pH}$ value, which affects protein denaturation, development of texture, and release of water (CANDOĞAN, 2000). It was seen that sample 2 had the lowest TA value as $1.02 \%$, while sample 7 had the highest TA value as $2.25 \%$, which is expressed as the percentage of lactic acid $(\mathrm{P}<0.05)$. Similar TA values of traditional fermented sausages were also reported by many researchers (CANDOĞAN, 2000; Franco et al., 2002; Ensoy et al., 2010).

The water activity $\left(\mathrm{a}_{\mathrm{w}}\right)$ values of bez sucuks were in a range of $0.843-0.958$, and both the lowest and the highest $\mathrm{a}_{\mathrm{w}}$ values in the sample 3 and 8 , respectively, were obtained from the butchers $(\mathrm{P}<0.05)$. KAVAL and co-workers $(2010)$ reported that $\mathrm{a}_{\mathrm{w}}$ values of bez sucuks commercially offered for sale were between $0.774-0.978$. The results also showed that the bucthers started to sell bez sucuks of unstandard quality parameters right after the filling stage.

To evaluate the color properties of bez sucuks, CIE L*a*b* values were measured (Table 2). The $\mathrm{L}^{*} \mathrm{a} * \mathrm{~b} *$ values of bez sucuks were in the ranges of 38.99-47.15, 10.77-20.94, and 13.88-32.41, respectively. The difference between the groups were statistically significant $(\mathrm{P}<0.05)$. While the lowest $\mathrm{L}^{*}$ value was measured in sample 2, sample 7 had the highest $\mathrm{L}^{*}$ value. Both samples were obtained from butchers $(\mathrm{P}<0.05)$. The sucuk samples bought from small facilities had similar $L^{*}$ values $(\mathrm{P}>0.05)$. Although, a* values of the samples 1 and 4 obtained from the small facilities were 17.14 and 19.11 , respectively $(\mathrm{P}>0.05)$, the highest $\mathrm{a}^{*}$ value was measured in sample 3 as $20.94(\mathrm{P}<0.05)$. The $\mathrm{b}^{*}$ values of sucuks were also in the wide range of 13.88-32.41, the lowest and highest values were determined from the samples 1 and 4 , respectively $(\mathrm{P}<0.05)$. It was found that the samples 1,2 , and 4 , containing residual nitrite, had similar $\mathrm{a}^{*}$ values $(\mathrm{P}>0.05)$. TuRHAN and co-workers $(2010)$ reported that the $\mathrm{L}^{*}$, $\mathrm{a}^{*}$, and $\mathrm{b}^{*}$ values of bez sucuks were in the ranges of $31.69-40.47,5.46-16.58$, and $9.32-$ 16.76, respectively. In another study, ÜREN and BABAYIĞIT (1997) determined that the L*, a*, and $b^{*}$ values of Turkish sucuks of eleven different manufacturers were in the ranges of 42.3-53.3, 11.3-20.4, and 11.5-26.2, respectively. The researchers also stated that the different formulations and unstandard processing conditions resulted in different colour properties of bez sucuks and Turkish sucuks.

Lipolysis caused by both endogenous and exogenous enzymes increases the free fatty acidity, and the oxidation products of free fatty acids, such as aldehydes and ketones, have significant effects on the flavour of fermented sausages (JoHANSSON et al., 1994). The ripening periods of bez sucuks and both the quality and the amount of meat and fat differ by each manufacturer (KAVAL et al., 2010), thus the free fatty acidity values of sucuks were between $3.01 \%$ and $14.34 \%$ oleic acid (Table 2) $(\mathrm{P}<0.05)$. Samples 1 and 4 , obtained from facilities, had similar FFA values $(\mathrm{P}>0.05)$. While butchers manufacture bez sucuks without starter culture and antioxidants, it is known that small facilities use sodium ascorbate as an antioxidant in the formulation. It was determined that the PV of sucuks were between 7.40 and 13.63 meq $\mathrm{O}_{2} / \mathrm{kg}(\mathrm{P}<0.05)$. The highest PVs were measured in samples 1,5 , and 6 as 


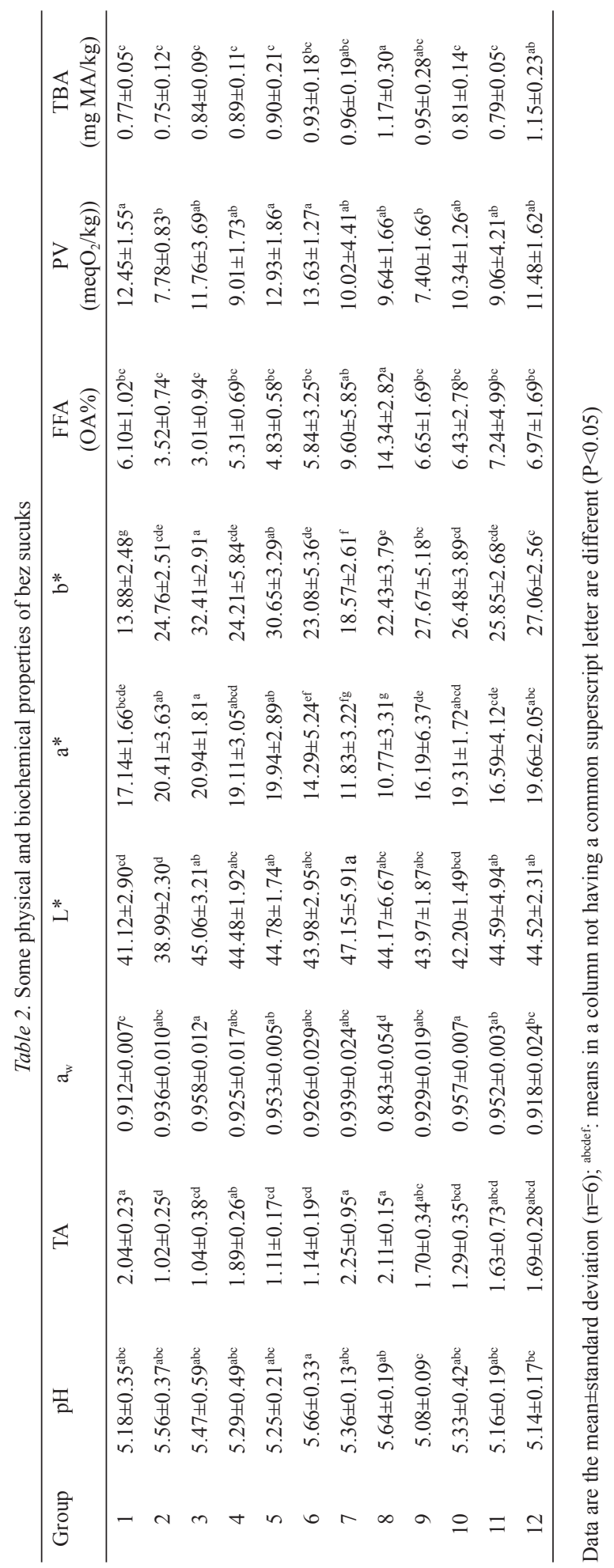


$12.45,12.93$, and 13.63 meq $\mathrm{O}_{2} / \mathrm{kg}$, respectively, while the sample 9 had the lowest peroxide value as 7.40 meq $\mathrm{O}_{2} / \mathrm{kg}(\mathrm{P}<0.05)$ (Table 2). SALGADO and co-workers (2005) reported that the peroxide values of chorizo's produced at home and in facilities were 9.71 and $11.6 \mathrm{meq}$ $\mathrm{O}_{2} / \mathrm{kg}$, respectively. In another study, the peroxide value of Androlla, a traditional Spanish fermented sausage, was determined as $28.28 \mathrm{meq}_{2} / \mathrm{kg}$ (FrANCO et al., 2002). TBA value is the main criterium to evaluate the lipid oxidation of unsaturated fatty acids, which results in an increase in malondialdehyde (MA) amount. The acceptable maximum TBA value of Turkish sucuks should be lower than $1.0 \mathrm{mg} \mathrm{MA} / \mathrm{kg}$ (TurP \& SERDAROĞLu, 2008). In our study, it was determined that the lowest TBA value was measured in sample 2 as $0.75 \mathrm{mg}$ $\mathrm{MA} / \mathrm{kg}$, while sample 8 had the highest TBA value as $1.17 \mathrm{mg} \mathrm{MA} / \mathrm{kg}$; both samples were obtained from butchers $(\mathrm{P}<0.05)$ (Table 2$)$. The TBA values of samples 1 and 4 manufactured by small scaled facilities were 0.77 and $0.89 \mathrm{mg} \mathrm{MA} / \mathrm{kg}$. TURP and SERDAROĞLU (2008) noted that the TBA value of Turkish sucuks produced with beef carcass fat was $0.6 \mathrm{mg} \mathrm{MA} / \mathrm{kg}$. The result stated by the researchers was lower in comparison with the TBA values of bez sucuks; this could be explained by the utilization of sodium ascorbate and the higher amounts of sodium nitrite. BOZKURT and ERKMEN (2007) investigated the effects of different commercial additives on the properties of Turkish sucuks; the researchers reported that the sucuk group without nitrite had TBA value of $1.64 \mathrm{mg} \mathrm{MA} / \mathrm{kg}$, while the TBA values of nitrite added groups were between 1.03 and $1.67 \mathrm{mg} \mathrm{MA} / \mathrm{kg}$. The results of both control and sodium nitrite added groups were higher than the TBA values of bez sucuks.

\section{Conclusions}

In recent years, the consumption and the production of Turkish fermented sausage like bez sucuk have increased. The present study investigated the properties of bez sucuk to see if this product is manufactured according to the recommendations stated in food legislation. According to the results of this study, the manufacturing conditions and the formulation showed differences among manufacturers. It was determined that proximate compositions of six $(1,4,6,7,8$, and 9) out of 12 samples met the requirements of the sucuk standard and the communique. On the other hand, it was seen that the moisture contents of bez sucuks obtained especially from butchers were in a wide range, and high moisture content, which improves the microbial growth, has an important effect on food safety. The results of this study will assist sausage manufacturers to alter the food formulation and processing parameters to comply with the regulatory standards.

This study was supported by Gaziosmanpaşa University Scientific Research Project Funding (BAP 2009/08).

\section{References}

AOAC (1996): Official methods of analysis. Association of Official Analytical Chemists (method no. 940.28). IAC, Arlington, VA.

AOAC (2006): Official methods of analysis. (Methods numbered as 950.46, 928.08, 960.39, and 920.153). Association of Official Analytical Chemists, Maryland.

AOCS (1994): Official methods and recommended practices of the American Oil Chemists Society (Method no. Cd 8b-90). Champaign, Illinois.

Bligh, E.G. \& DYeR, W.J. (1959): A rapid method for total lipid extraction and purification. Can. J. Biochem. Phys., $37,911$. 
Bozkurt, H. \& ERKMEN, O. (2004): Effects of temperature, humidity and additives on the formation of biogenic amines in sucuk during ripening and storage periods. Food Sci. Technol. Int., 10(1), 21-28.

Bozkurt, H. \& ERKMEN, O. (2007): Effects of some commercial additives on the quality of sucuk (Turkish dryfermented sausage). Food Chem., 101, 1465-1473.

CANDOĞAN, K. (2000): Bacterial starter cultures, aging and fermentation effects on some characteristics of fermented beef sausages. Clemson University, Thesis of Doctor of Philosophy of Food Technology, Clemson, USA. p. 35.

Ensoy, Ü., Kolsarici, N., CandoĞan, K. \& Karslioğlu, B. (2010): Changes in biochemical and microbiological characteristics of turkey sucuks as affected by processing and starter culture utilization. J. Muscle Foods, 21(1), 142-165.

Franco, I., Prieto, B., Cruz, J.M., Lopez, M. \& Carballo, J. (2002): Study of the biochemical changes during the processing of Androlla, a Spanish dry-cured pork sausage. Food Chem., 78, 339-345.

Johansson, G., Berdague, J.L., Larsson, M., Tran, N. \& Borch, E. (1994): Lipolysis, proteolysis and formation of volatile components during ripening of a fermented sausage with Pediococcus pentosaceus and Staphylococcus xylosus as starter cultures. Meat Sci., 38, 203-218.

KaVal, N., ÖncüL, N., YILDIRIM, Z. \& Ensoy, Ü. (2010): Tokat bez sucuğunun mikrobiyolojik niteliklerinin incelenmesi (The evaluation of microbiological properties of Tokat bez sucuk). The 1st International Symposium on Traditional Foods from Adriatic to Caucasus. Tekirdağ, Turkey. p. 418

LEEs, R. (1975) Food analysis: Analytical and quality control methods for the food manufacturer and buyer. Leonard Hill Books, London, 245 pages.

Republic of Turkey Ministry of Food, Agriculture and Livestock (2012): Turkish Food Codex - Meat and Meat Products Communique. Communique number, 2012/74 (http://tarim.gov.tr/Mevzuat/Turk-Gida-Kodeksi). (Accessed December 05, 2012).

Republic of Turkey Ministry of Food, Agriculture and Livestock (2013): Turkish Food Codex - Food Additives Regulation (http://tarim.gov.tr). (Accessed June 30, 2013).

Salgado, A., Fontan, M.C.G., Franco, I., Lopez, M. \& Carballo, J. (2005): Biochemical changes during the ripening of Chorizo de Cebolla, a Spanish traditional sausage. Effect of the system of manufacture (homemade or industrial). Food Chem., 92, 413-424.

Tarladgis, B.G., Watts, B.M., Younathan, M.T. \& Dugan, Tr.L. (1960): A distillation method for the quantative determination of malonaldehyde in rancid foods. J. Am. Oil Chem. Soc., 37, 44-48.

TSE (2002): Türk Sucuğu Standardı (Turkish Sucuk Standard, TS 1070), Türk Standardları Enstitüsü, Ankara (2002), (http://www.tse.org.tr).

Turhan, S., Temız, H. \& ÜstüN, N.Ş. (2010): Bez sucukların bazı fiziksel ve kimyasal özelliklerinin belirlenmesi (The determination of some physical and chemical properties of bez sucuks). The 1st International Symposium on Traditional Foods from Adriatic to Caucasus.Tekirdağ, Turkey, pp. 422-424.

TurP, G.Y. \& SerdaroğLu, M. (2008): Effect of replacing beef fat with hazelnut oil on quality characteristics of sucuk - A Turkish fermented sausage. Meat Sci., 78, 447-454.

Üren, A. \& BABAYIĞIT, D. (1997): Colour parameters of Turkish-type fermented sausage during fermentation and ripening. Meat Sci., 45, 539-549.

VURAL, H. \& ÖZTAN, A. (1996): Kalıntı nitrit miktarının saptanması (The determination of residual nitrite amount). -in: Vural, H. \& ÖZTAN, A. (Eds): Et ve ürünleri kalite kontrol laboratuvarı uygulama kilavuzu, (Quality control laboratory practice guide for meat and meat products), Ankara: H.Ü. Mühendislik Fak. Yayınları, pp. $87-88$.

YANG, T.S. \& FRONING, G.W. (1992): Changes in myofibrillar protein and collagen content of mechanically deboned chicken meat due to washing and screening. Poultry Sci., 71, 1221-1227. 